\title{
Mycosylva reticulata, a new psychrophilic hyphomycete
}

\author{
RobertA. Samson and VeikkoHintikka
}

\begin{abstract}
Centraalbureau voor Schimmelcultures, Baarn, the Netherlands and Finnish Forest Research Institute, Unioninkatu $40 \mathrm{~A}$, Helsinki 17, Finland.

Abstract: A new synnematous hyphomycete, Mycosylva reticulata Samson \& Hintikka sp.nov. is described. It has been isolated from pellets of small rodents in northern Finland and differs from the type culture of $M$. clarkii Tulloch mainly by the reticulate ornamentations of the conidia, the presence of ramoconidia and the olive green colour of the synnematal heads. Mycosylva clarkii and $M$. reticulata are psychrophilic, showing optimal growth at $15^{\circ} \mathrm{C}$. The relationship of the genus Mycosylva to Myceliophthora, Hormoconis, Pycnostysanus and Heydenia is discussed.
\end{abstract}

\section{INTRODUCTION}

During attempts to obtain psychrophilic basidiomycete mycelia from forest soil and litter in Finland an interesting hyphomycete was isolated from pellets of small rodents. The fungus produced typical synnemata on agar media. Recently a similar fungus was isolated from animal droppings in England and described in a new genus as Mycosylva clarkii by Tulloch (1973). After comparison with the type culture of $M$. clarkii it was shown that the Finnish isolate differed sufficiently to warrant its description as a new species.

Mycosylva reticulata Samson \& Hintikka, spec. nov.

Coloniae in agaro maltosa $15^{\circ} \mathrm{C}$ lente crescunt; $e$ strato velutino synnemata numerosa in orbes concentricos disposita, in medio dense aggregata oriuntur. Synnemata capitata, 4-6 $\mathrm{mm}$ alta; stipes fere niger, cylindricus, $3.5-5.5 \mathrm{~mm}$ longus, $100-350 \mu \mathrm{m}$ crassus, e hyphis parallelis fuscis, levibus vel asperulis, 3-5 $\mathrm{um}$ crassis compositus; capitulum primum flavidum, deinde obscure viride vel olivaceum, $600-1500 \times 600-1000 \mu \mathrm{m}$. Capitula e hyphis fertilibus composita, hya- linis, primum levibus, deinde granulis flavis incrustatis et plus minusve pigmentatis, 1.7$2.5 \mu \mathrm{m}$ in diam. Cellulae conidiogenae monovel polyblasticae, globosae vel ellipsoideae, intercalares, laterales vel terminales, $3-6 \times$ 2.5-4 $\mathrm{um}$. Conidia holoblastica, in catenis brevibus acropetalibus connexa, continua, globosa vel ellipsoidea, flavo-brunnea vel brunnea, primum levia, deinde reticulata, $3.5-4.0 \times 3.0-3.5 \mu \mathrm{m}$. Hyphae fertiles in ramoconidia cylindrica longitudinis variabilis secedunt, $7.5-12.0 \times 2.0-2.5 \mu \mathrm{m}$, asperula vel reticulata.

Typus CBS 448.71, isolatus ex excrementis parvorum rodentiorum in silva mixta boreali, collina Kaihuanvaara, in Fennia septentrionali.

Colonies grow slowly on malt agar at $15^{\circ}$ $\mathrm{C}$, attaining a diameter of about $3.5 \mathrm{~cm}$ within one month, consisting of a dense felt from which numerous synnemata arise usually in concentric rings, densely grouped towards the centre of the colony. Synnemata capitate, 4 to $6 \mathrm{~mm}$ high, stalk dark almost black, cylindrical, $3.5-5.5 \mathrm{~mm}$ long and 100 $-350 \mu \mathrm{m}$ thick, consisting of parallel hyphae, which are dark, smooth-walled to slightly roughened, 3--5 $\mu \mathrm{m}$ wide, apically splaying 

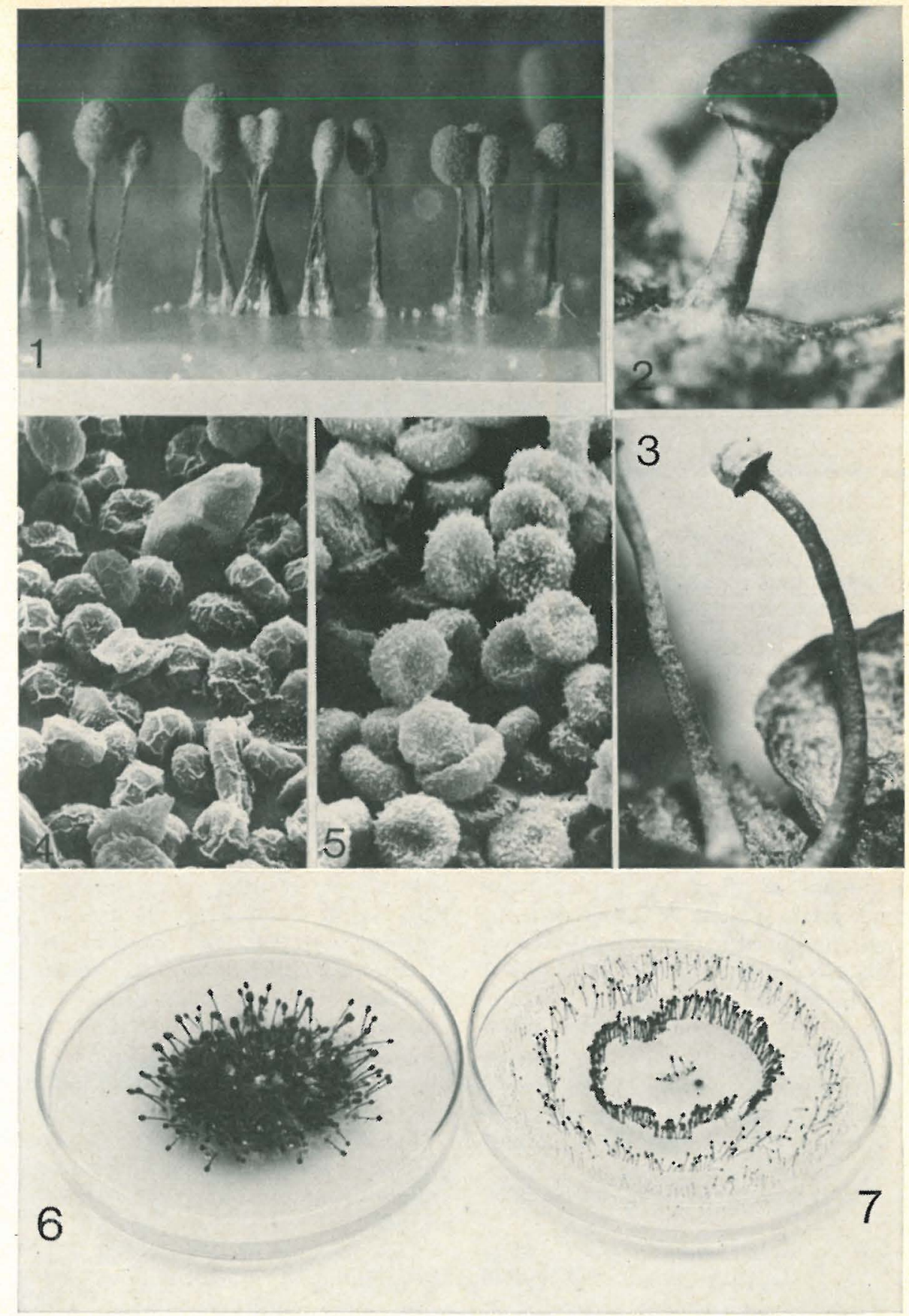

Figs. 1-7. - Fig. 1: Mycosylva reticulata on malt agar, $+15^{\circ} \mathrm{C}(35 \mathrm{x})$. Fig. 2: Heydenia americana, fruitbody with peridium $(20 \mathrm{x})$. Fig. 3: Heydenia alpina (7 x). Fig. 4: Mycosylva reticulata and Fig. 5: $M$. clarkii, SEM micrographs $(3000 \mathrm{x})$. Fig. 6: $M$. reticulata on PDA and Fig. 7 on $1 \%$ malt agar at $15^{\circ} \mathrm{C}(0.5 \mathrm{x})$.

out to form a subglobose to ellipsoidal head; head yellowish at first near Martius Yellow to Picric Yellow (Ridgway, 1912, Pl. 4), later becoming dark green near Dark Citrine to Olive Green (Ridgway, Pl. 16), 600-1500 $\times 600-1000 \mu \mathrm{m}$. The heads consist of fer- 
tile hyphae, which are hyaline and smoothwalled at first, becoming encrusted with yellow granula and later slightly to dark pigmented, $1.7-2.5 \mu \mathrm{m}$ in diameter. Conidiogenous cells mono- or polyblastic, globose to ellipsoidal, intercalary, lateral or terminal, $3-6 \times 2.5-4.0 \mu \mathrm{m}$. Conidia holoblastic, produced in short acropetal chains, onecelled, globose to ellipsoidal 3.5-4.0 $\times 3.0$ $3.5 \mu \mathrm{m}$, yellow brown to brown, smooth when young, later becoming ornamented with reticulate structures, which are readily seen under the light microscope. The fertile hyphae break apart into ramoconidia of variable size and shape, mostly cylindrical, $7.5-12.0 \times 2.0-2.5 \mu \mathrm{m}$, roughened to reticulate.

Colonies on oatmeal-agar at $15^{\circ} \mathrm{C}$ show a zonate growth, synnemata are produced in concentric rings about $1 \mathrm{~cm}$ apart. Colonies on PDA agar similar to those on malt agar (Figs. 1, 6 and 7), but synnemata usually longer, up to $7 \mathrm{~mm}$ in length.

Influence of temperature: Optimal growth occurs at $15^{\circ} \mathrm{C}$; no growth was observed at temperatures above $25^{\circ} \mathrm{C}$. In cultures grown at $25^{\circ} \mathrm{C}$ in an incubator, the conidia germinate on malt agar and little mycelium is visible after 14 days. The colonies consist only of sterile mycelium. At $4^{\circ} \mathrm{C}$ growth is very slow. Typical synnemata are however produced after one month.

Culture examined:

CBS 448.71 = type culture of Mycosylva reticulata, isolated from pellets of small rodents in a mixed boreal forest (Betula pubescens, Picea excelsa), Kaihuanvaara hill, Rovaniemi Commune, northern Finland.

\section{Discussion:}

The cultural appearance and the synnematal habit of Mycosylva reticulata is similar to that of $M$. clarkii Tulloch (type culture = CBS $608.73=$ IMI 163,345). In the two species the same influence of temperature is observed: both are psychrophilic with an optimal growth at $15^{\circ}$ C. M. reticulata differs, however, from $M$. clarkii by the olive green colour of the synnematal heads, the production of ramoconidia and the reticulate conidia (Fig. 4 and 5). In $M$. reticulata the heads are Dark Citrine to Olive Green (Ridgway, Pl. 16), while they are Lettuce Green to Spinach Green (Ridgway, Pl. 5) in $M$. clarkii. In the latter species the conidia are smooth-walled to finely roughened, and arise from more or less cylindrical conidiogenous cells. In $M$. reticulata these cells are globose to ellipsoidal. Another morphological difference between $M$. clarkii and $M$. reticulata are the fertile hyphae, which are straight in $M$. reticulata, while they are twisted in $M$. clarkii (Fig. 8).

Tulloch (1973) considered Mycosylva clarkii as being related to Chrysosporium luteum (Cost.) Carmichael. This fungus was described as the type species of the genus Myceliophthora Cost. and can be distinguished from the typical Chrysosporium species by narrow apiculate conidia, probuced in short chains. In Chrysosporium species the conidia are produced singly with a broad truncate base. A generic delimitation between Myceliophthora and Chrysoporium seems therefore desirable (voN ARx, 1973).

The polyblastic conidiogenous cells and the catenate conidia of the two species of Mycosylva resemble also those of the genera Hormoconis von Arx \& de Vries apud von Arx (1973) (type species: Hormodendron resinae Lindau = Cladosporium resinae (Lindau \& de Vries) and Cladosporium Link ex Fr. The synnematous nature of Mycosylva distinguishes it from both genera.

Among the stilbaceous fungi, Mycosylva may be related to the genus Pycnostysanus Lindau as accepted by Morris (1963) and Barron (1968). However the systematic position of Pycnostysanus seems uncertain, because the type species, $P$. resinae Lindau, has been confused with some other species with the same epithet. The genus Pycnostysanus was described by LiNDAu (1903), who placed it later (1910) in synonymy with Stysanus resinae (Fr.) Lindau together with Rhacodium resinae Fr., Sporocybe resinae Fr. and Myxotrichum resinae Fr. The latter species is placed by Ellis (1970) in the genus Alysidium Kunze ex Schm. Since conidium ontogeny in the above mentioned species is similar and can easily result in a confusion of these fungi, the taxonomy urgently needs revision.

By the synnematal habit and the psychrophily, Mycosylva resembles the genus Heydenia as described and illustrated by Fresenius (1852). Heydenia alpina Fres. and H. americana Sacc. \& Ellis (1882) are reported as alpine (Heim, 1934, Nicot, 1970 and BeL- 
LER \& Roux, 1971) and are only known from herbarium specimens collected on plant material. The species are characterized by hard, stipitate, synnema-like fruit bodies, which widen disk-like at the apex (Fig. 2 and 3). The heads of young fruit bodies are covered by a thin peridium, thus resembling stipitate pycnidia. Since the studied specimens did not allow examination of conidium ontogeny, attempts were made to isolate $H$. americana in pure culture from fresh specimens, collected by Prof. E. Müller (Zürich) on Juniperus nana at the Bernina Pass (Switzerland). However, on agar media as well as on sterilized plant material only sterile mycelium and no synnemata or conidia could be observed. According to Fresenius (1852) the conidia were formed in chains directly from the fertile hyphae. This feature could not be demonstrated in the specimens studied. In some specimens scars on the fertile hyphae were observed probably left by the production of blastic conidia.

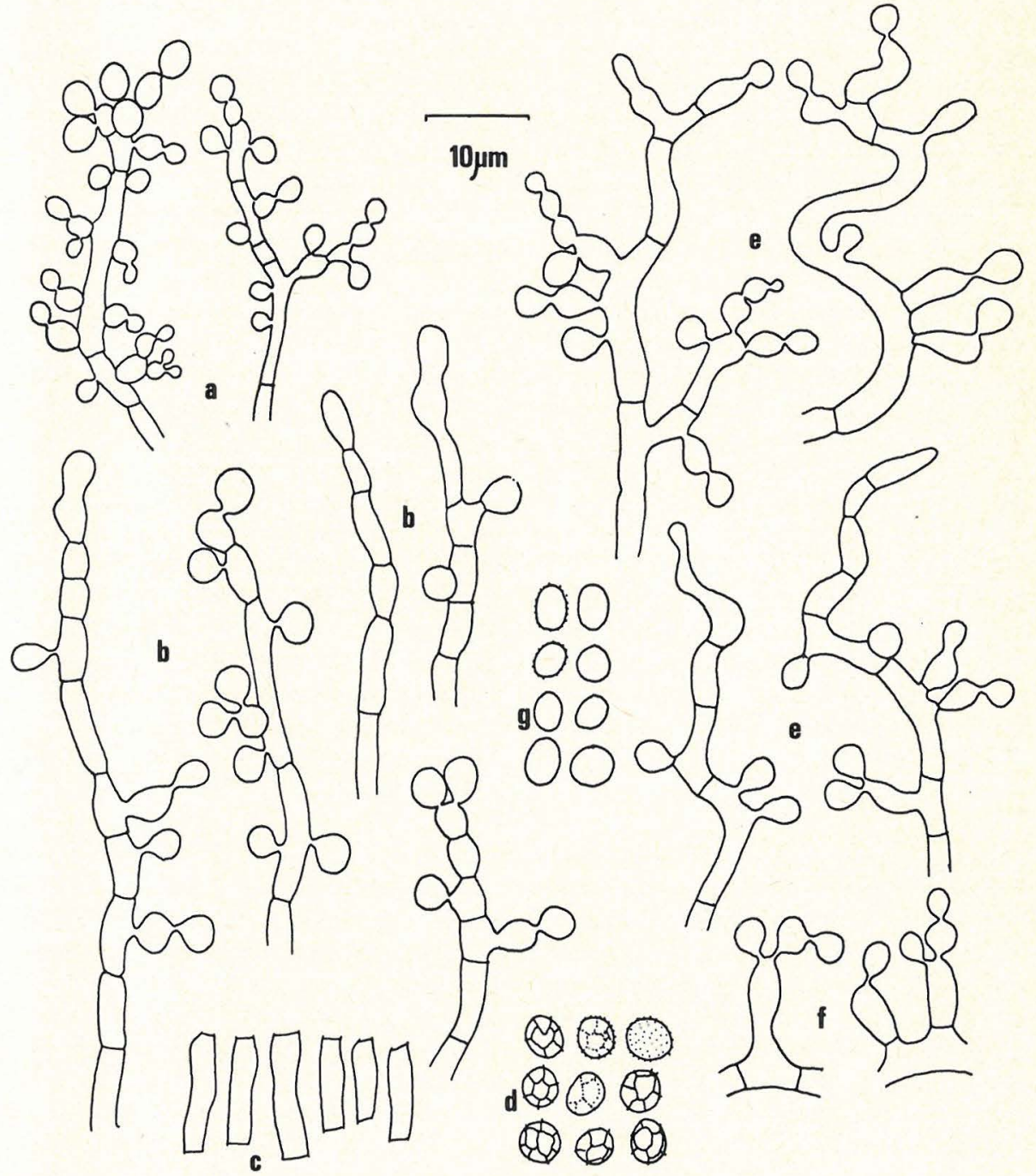

Fig. 8. a-d Mycosylva reticulata. a: young conidial structures. b: conidial structures on straight fertile hyphae. c: ramoconidia. d: conidia. e-g Mycosylva clarkii. e: conidial structures on twisted fertile hyphae. f: conidiogenous cells. g: conidia. 


\section{REFERENGES}

ARx, J. A. von, 1973: Further observations on Sporotrichum and some similar fungi. Persoonia 7 (2): $127-130$.

ARx, J. A. von, 1973: Centraalbureau voor Schimmelcultures, Baarn and Delft. Progress Report. - Verh. k. ned. Akad. Wet., Aft. Naturk., 2e Reeks 61(4): 59-81.

Barron, G. L., 1968: The genera of Hyphomycetes from soil. - Williams \& Wilkins, Baltimore, 364 pp.

Beller, J. \& G. Roux, 1971: Une récolte pyrénéenne rare ... ou l'histoire d'un faux myxomycète. Heydenia alpina Fres. - Bull. Inf. Soc. mycol. Bern no. 44: 1-3.

Ellis, M. B., 1971: Dematious Hyphomycetes, Commonwealth Mycological Institute, Kew, 608 pp.

Fresenius, G., 1850-1863: Beiträge zur Mykologie. - Frankfurt. 108 pp.

HeIm, R., 1934: Fungi Iberici. - Treballs Mus.
Cienc. Nat. Barcelona. vol. 15 ser. bot. no. 3 .

Lindau, G., 1903: Beiträge zur Pilzflora des Harzes. - Verhandl. Bot. Ver. Prov. Brandenb. XLV: $149-161$.

Lindau, G., 1910: Die Pilze IX. Fungi Imperfecti; in Rabenhorst's Kryptogamenflora. Leipzig.

Morris, E. F., 1963: The synnematcus genera of the Fungi Imperfecti. - Western Illin. Univ. Ser. biol. Sci. 3: 1-143.

Nicot, J., 1970: Quelques récoltes remarquables de Micromycètes. - Rev. Mycol. 35: 222226.

Ridgway, R., 1912: Color standards and color nomenclature. - Washington, DC.

SACcardo, P. A., 1882: Michelia, commentarium mycologicum. Vol. II- PATAVII.

Tulloch, M., 1973: A new synnematous hyphomycete. - Trans. Br. mycol. Soc. 60: 155-157. 